\title{
幼木茶園における省力管理作業の体系化試験
}

宮崎県総合農試茶業支場 䚗島 斉 - 德永保利 - 楠原俊秋

\section{Studies on Organization of Labour-saving Management in the Young Tea Field}

\author{
By Hitoshi Sameshima, Yasutoshi Tokunaga \\ and Toshiaki KUSUHARA
}

Tea Branch, Miyazaki Agricultural Experiment Station

\section{1 ま がき}

1966年著者らは，地域標準技術体系，畑作 No. 3〔自 走型動力摘採機を中心とする緑茶の機械化裁培技術体 系つ一南九州地域に打汁る一の策定を終えたのである が，実はこの標準技術体系が成立し得るためには整備さ れている成木茶園が前提条件となるが，かかる園が南九 州には眼に沢山存在していた訳ではなかった。むしろこ れから造成される茶園は上記の標準技術体系を駆使でき るよう設計されるべきであろうといら一っのめやすが与 光られたに過ざないという誠に橉切れの悪いるのでしか なかった。すなわち，機峨化茶園をいかに効率よく造成 するか；この命題に明快な答を出すことができなけれ ば;この標準技術体系もまた，デスクプランの域を出な いものになってしまらと思われた。

このよ5な背景のもとに，從来誠にノンどリとしてい た茶園造成の技術は，奻木茶園造成の省力体系化技術の 確立を目指し根底から洗い直す必要に迫られた。

本陚験は 1966〜1970年にわたりこの地域における幼木
茶園管理技術の問題点を䅅営的側面（早期成園化）から とらえよ5とする中で，今後の研究目標を明らかにする ことを意図した。

したがって本試験は第一段階として茶園を大規模に造 成管理する試験調查漂場を場内に設定し，この生育経過 の中から経営上の問題点を明らかにし，栽培上の個別的 技術の苚価と再検討を試みよ5としたるのである。

試験年次途中に打いて研究課題の編成替えなどによ り，調查の手法など変更を余儀なくされた面もあるが， これらの試験結果が基礎となって，現在実施中の早期成 園化技術体柔の確立に䦛する研究の指標が樹立されたも のであることを，念のため付記しておく。

\section{2 試 験 方 法}

素材研究から得られた情報，技術を省力化と早期成園 化の両面から自走型動力摘採機を主軸とした 5 ha の幼木 茶園管理作業の体系を組み立て，茶園造成より 5 年目ま での育成過程を追跡した。この組み立て体系の実施の過 程で提起された問題点を究明して，その結果を技術組み

表 110 a 当たり 3 要素の施肥基準 $(\mathrm{kg} / 10 \mathrm{a})$

\begin{tabular}{|c|c|c|c|c|c|c|c|c|c|c|c|c|c|c|c|}
\hline 樹龄 & 定 & 直 & 年 & 2 & 年 & 生 & 3 & 年 & 生 & 4 & 年 & 生 & 5 & 年 & 生 \\
\hline 期 & $\mathrm{N}$ & $\mathbf{P}$ & $\mathbf{K}$ & $\mathrm{N}$ & $\mathrm{P}$ & K & $\mathrm{N}$ & $\mathrm{P}$ & $\mathrm{K}$ & $\mathrm{N}$ & $P$ & $\mathrm{~K}$ & $\mathrm{~N}$ & $\mathbf{P}$ & $\mathrm{K}$ \\
\hline “秋肥 & & 4 & & 13 & 8 & 8 & 15 & 9 & 9 & 18 & 10 & 10 & 20 & 11 & 11 \\
\hline 春 肥 & & 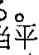 & & 13 & 4 & 4 & 15 & 5 & 5 & 18 & 10 & 10 & 20 & 11 & 11 \\
\hline 夏肥 I & & -4 & & 8 & 4 & 4 & 10 & 5 & 5 & 12 & 8 & 8 & 13 & 9 & 9 \\
\hline 夏肥 II & & & & 8 & 4 & 4 & 10 & 5 & 5 & 12 & - & - & 13 & - & - \\
\hline 間 & 16 & 8 & 8 & 42 & 20 & 20 & 50 & 24 & 24 & 60 & 28 & 28 & 66 & 31 & 31 \\
\hline
\end{tabular}

。施 用 法

定植当年：株元より $10 \mathrm{~cm}$ 離して施用 $2 \sim 3$ 年生：株元より $20 \mathrm{~cm}$ 離して $30 \sim 40 \mathrm{~cm}$ 愊に 散布後かく拌
4 年生以上：5被全面散布後かく拌

\{秋肥：なるべく深尿部施男

春肥・夏肥：浅くかく拌

。有機質肥料：秋肥・春肥施用NO50\%施用 
立て試験の過程で活用し，技術体系のレペルアップをは かるよらにした。

\section{1 供試ほ場}

1966年 1 月に深さ $40 \mathrm{~cm}$ ，幅 $40 \mathrm{~cm}$ の定植赦を慣行法 で作り，有機質資材約 $1,500 \mathrm{~kg}$ を施用後覆士した。

供試面積 $62 \mathrm{a}(72 \mathrm{~m} \times 86.4 \mathrm{~m})$

裁植方法 $160 \mathrm{~cm} \times 30 \mathrm{~cm} \quad 1$ 条植

定植時期 1966年 3 月，供誤品種やぶきた
定植後の肥培方法は表1に示すと抢りである。

また，この試験を推進するに当たって瑟備した扣すな 豊業機械類は表 2 のと括りである。

\section{2 作業体系基準}

管理作業については，定植第 3 年目よりは表 3 の作業 体系基淮をあらかじめ設計しておき，これ炕基づいて管 理した。

表 2 農業機械

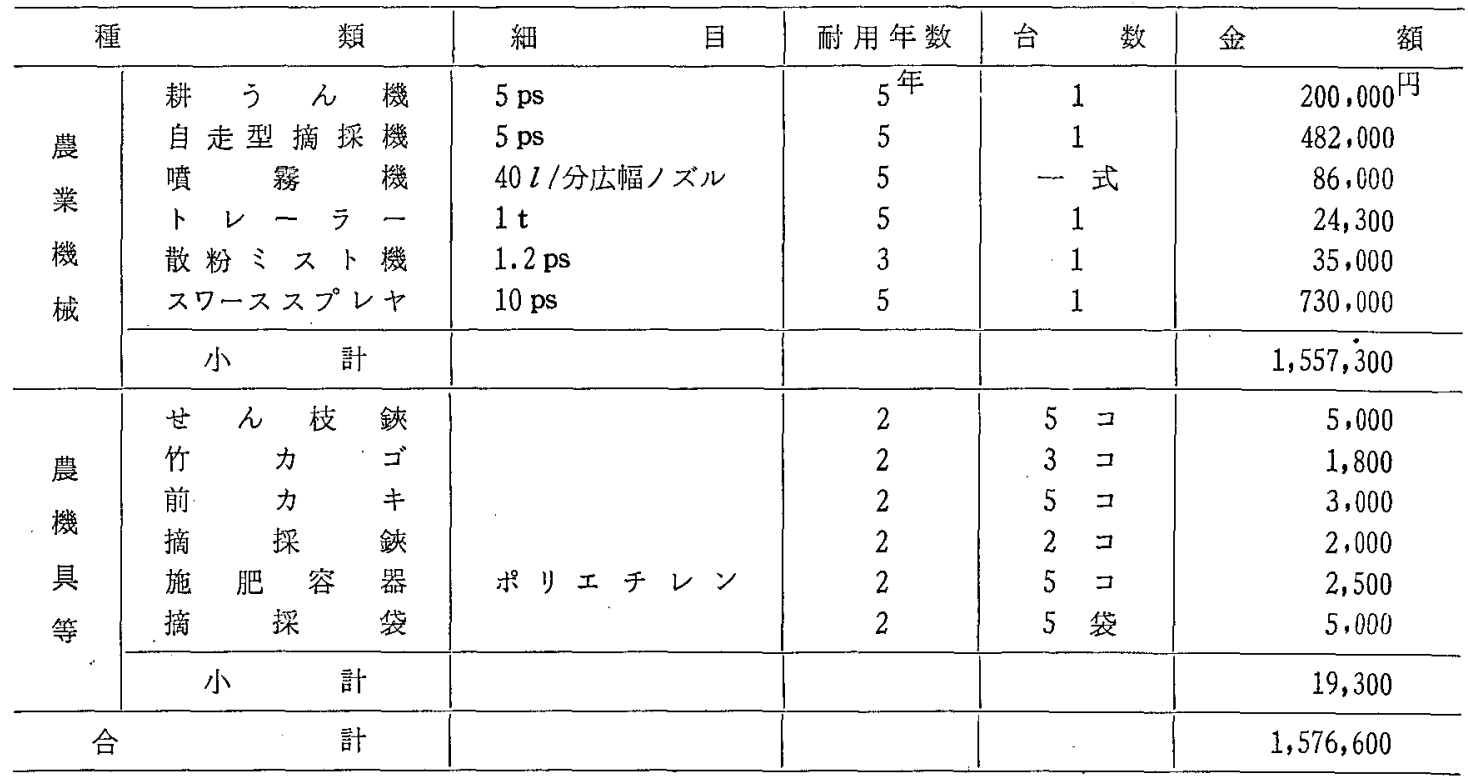

表 3 作業体柔基準 (10 a )

\begin{tabular}{|c|c|c|c|c|c|c|c|}
\hline & 作 業 名 & 作 & 業 機 械 & 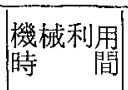 & $\begin{array}{l}\text { 延労锶 } \\
\text { 時 間 }\end{array}$ & 使用資材費 & 備 \\
\hline \multirow{3}{*}{ 第 } & 敷方 ら & \multicolumn{2}{|r|}{ - } & 時間 & $\begin{array}{l}\text { 時間 }^{-15} \\
\end{array}$ & $1,000 \mathrm{~kg}$ & 10 月株元両側 $30 \mathrm{~cm}$ \\
\hline & う水間除草 & \multicolumn{2}{|c|}{5 ps 鉈爪ロローターーーター } & 4 & 4 & & $\begin{array}{c}10,12,3,4,5, \\
6,7,8 \text { 月耕梁 } 5 \mathrm{~cm}\end{array}$ \\
\hline & 株元除草 & & & - & 5 & - & $4 \sim 8$ 月 \\
\hline 3 & 防除 & 5 ps & 広幅散布ノズル & 0.9 & 5.4 & 2,900 & $\begin{array}{l}2 \text { 月下, } 4 \text { 月上, } 6 \text { 月上 } \\
7 \text { 月上, } 8 \text { 月卡, 9月 } \\
9 \text { 月中, } 10 \text { 月上, } 11 \text { 月上 }\end{array}$ \\
\hline \multirow[t]{2}{*}{ 年 } & 施肥 & $5 \mathrm{ps}$ & 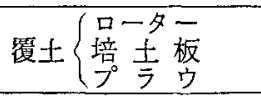 & 3.5 & 55.2 & 17.000 & 9 月上， 3 月上， 6 月上 \\
\hline & 初回せ九枝 & 5 ps & 自走型せん枝機 & 1.2 & 7.4 & & 3 月上 \\
\hline \multirow{2}{*}{ 目 } & 摘採, 整枝 & 5 ps & 自走型摘採譏 & 2.4 & 4.8 & & $\begin{array}{l}\text { 摘採 } 5 \text { 月上, } \\
\text { 整枝 } 5 \text { 月中, } 10 \text { 月 }\end{array}$ \\
\hline & 䚵 & & & 12 & 96.8 & 26,500 & \\
\hline
\end{tabular}




\begin{tabular}{|c|c|c|c|c|c|c|}
\hline & 作 業 名 & 作 業 譏 械 & 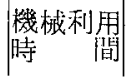 & \begin{tabular}{|l|} 
延労嗺 \\
時
\end{tabular} & 使用資材等 & 俑 \\
\hline \multirow{3}{*}{ 第 } & う权闍除草 & $5 \mathrm{ps}$ 鉈爪ローター & $\begin{array}{l}4^{\prime} \\
4\end{array}$ & $\begin{array}{l}\text { 㭙䦧 } \\
4\end{array}$ & & $\begin{array}{l}\text { 10月, 11月, 3月, } 4 \text { 月, } 5 \\
\text { 月, } 6 \text { 月, } 7 \text { 月, } 8 \text { 月, } 9 \text { 月 } \\
\text { 耕樑 } 5 \mathrm{~cm} \text {, 草丈 } 5 \mathrm{~cm}\end{array}$ \\
\hline & 株元除草 & $5 \mathrm{ps}$ 動力䔬霧機 & & 4 & 除 草 剂 & $4 \sim 8$ 月 \\
\hline & 防除 & $5 \mathrm{ps}$ 広幅散柨ノズル & 2.5 & 7.3 & & $\begin{array}{l}1 \text { 月下， } 3 \text { 月上， } 4 \text { 月中 } \\
5 \text { 月下， } 7 \text { 月上，8月上 } \\
8 \text { 月下下，9月_上，中 }\end{array}$ \\
\hline 4 & 施把 & $5 \mathrm{ps}$ ロータータ & 3.0 & 45 & $\begin{array}{r}\text { ノコクズ堆肥 } \\
750 \mathrm{~kg} \\
\end{array}$ & 9 月上, 3 月上, 6 月上 \\
\hline 年 & 檤採 & $5 \mathrm{ps}$ 自走型摘採機 & 3.0 & 4.2 & & 5 月上, 6 月下 \\
\hline \multirow[t]{2}{*}{ 目 } & 整 枝 & $"$ & 1.5 & 2.7 & & 2月下, 7 月下 \\
\hline & 計 & & 14.0 & 67.2 & & \\
\hline \multirow{3}{*}{ 第 } & うね間除草 & 5 ps 鉈爪ローター & 4 & 4 & & 10月, 11月，5月，6月 \\
\hline & ·株元除草 & & 2 & 10 & 除 草 剂 & $4 \sim 9$ 月 2 回秼元 \\
\hline & 防除 & 5 ps 広幅散行ノズル & 4 & 6.0 & & \\
\hline \multirow[t]{2}{*}{5} & 施肥 & $\begin{aligned} 5 \mathrm{ps} \text { ローター } & \text { 培土板, プラウ }\end{aligned}$ & 4 & 12 & 堆肥 $750 \mathrm{~kg}$ & \\
\hline & 摘採 & $5 \mathrm{ps}$ 自走型摘採機 & 4.8 & 10 & & 5 月上, 6 月下, 7 月下 \\
\hline 年 & 整枝 & $"$ & 3 & 6 & & 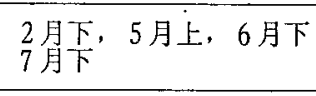 \\
\hline \multirow[t]{3}{*}{ 目 } & 土壤改良 & 5 ps 鉈爪口ーター & 0.5 & 1.0 & & \\
\hline & 線虫防除 & & 0.5 & 1.0 & DICP 粉剂 & 秋肥施用時 \\
\hline & 計 & & 22.8 & 50.0 & & \\
\hline
\end{tabular}

\section{3 実 験 結 果}

\section{1 茶樹の生育状態}

定植当年の造園関係作業は，その後の試験の展開に支 障を来たさないように配慮したため，慣行法により集約 的作業を実施したが，定植以後の管理については可能な 限り省力化のための技術配置を軸にしながら，思い切った 技術投入を試みたつもりである。このような管理方式の 中に批ける茶樹の生育経過を定植当年より 5 年目までま とめると表 4 のとおりである。

結果的には収量をみると 5 年目の収量は $732 \mathrm{~kg} / 10 \mathrm{a}$ であり，当初期待した $1,200 \mathrm{~kg} / 10 \mathrm{a}$ （5年目）には灌く 及ぶことはできず目標達成率は $60 \%$ にとどまったが，当
場におけるやぶきたを供試した他の試験の収量水準と汪 注同一程度のものであり，本試験において期待した活ど の肥料の増施効果等は全く認めることがで竞なかった。 秋期の茶樹の生育状態に打いても決して茶樹の衰弱した 傾向は見られないので，第 3 年目上り一举に仕立を兼ね て年 3 回収穫する方式を取り入れたが，樹勢への影㗽は なかった。ただ，観察の結果によれば，すべての管理を 機㖑化に期待した方式をとっているので，例点ば樹冠形 成のための分枝構成や着枝密度が適当か否かの点につい ては今後の検討課題の一つであると思われた。同じこと が摘採の機械化の問題に打いても提起され，水平型仕立 茶園の功罪はもとより，基本的炕機械摘探園の生理特 性のは握等基礎的な面の解明の必要性も痛感された。 
表 4 茶樹 の 生育経過

\begin{tabular}{|c|c|c|c|c|c|c|c|c|c|c|c|}
\hline & \multirow{2}{*}{ 生存率 } & \multicolumn{2}{|r|}{ 秋 9} & \multicolumn{3}{|c|}{ 生 育 状 態 } & \multicolumn{2}{|l|}{ 双 } & \multicolumn{2}{|c|}{ (10 a 当たり) } & \multirow{2}{*}{$\begin{array}{l}\text { 期街収量 } \\
\text { 出らびk } \\
\text { 達 成率 }\end{array}$} \\
\hline & & 樹 高 & 幹 径| & 分枝数 & 株張り & 母枝数 & 一番茶 & 二.香茶 & 三番茶 & 年 計 & \\
\hline $\begin{array}{l}\text { 定 } \\
\text { 植 } \\
\text { 荨 } \\
\text { 年 }\end{array}$ & $\begin{array}{l}2 \text { 年生苗 } \\
96.8 \\
1 \text { 年生苗 } \\
98.9\end{array}$ & $\begin{array}{l}\mathrm{cm} \\
41.6 \\
44.4\end{array}$ & $\begin{array}{l}\mathrm{mm} \\
8.5 \\
6.5\end{array}$ & $\begin{array}{r}9.4 \\
9.0 \\
.15 .1\end{array}$ & $\mathrm{~cm}$ & 本 & $\mathrm{kg}$ & $\overline{\mathrm{kg}}$ & $\mathrm{kg}$ & $\mathbf{k g}$ & \\
\hline $\begin{array}{l}2 \\
\text { 年 } \\
\text { 目 }\end{array}$ & $\begin{array}{l}2 \text { 年生苗 } \\
1 \text { 年生触 }\end{array}$ & $\begin{array}{l}102.9 \\
111.4\end{array}$ & $\begin{array}{l}13.7 \\
12.6\end{array}$ & $\begin{array}{l}22.1 \\
24.6\end{array}$ & $\begin{array}{l}68.8 \\
54.5\end{array}$ & $\begin{array}{l}58 \\
61\end{array}$ & & & & & \\
\hline $\begin{array}{l}3 \\
\text { 年 } \\
\text { 目 }\end{array}$ & $\begin{array}{l}2 \text { 年生苗 } \\
1 \text { 年生菌 }\end{array}$ & $\begin{array}{l}75 \\
70\end{array}$ & $\begin{array}{l}24.4 \\
19.2\end{array}$ & $\begin{array}{l}58 \\
61\end{array}$ & $\begin{array}{l}71 \\
66\end{array}$ & & 24.6 & 53.9 & 30.1 & 108.6 & $\begin{array}{c}180 \mathrm{~kg} \\
57 \%\end{array}$ \\
\hline $\begin{array}{l}\text { 告 } \\
\text { 年 } \\
\text { 目 }\end{array}$ & $\begin{array}{l}2 \text { 年生苗 } \\
1 \text { 年生苗 }\end{array}$ & $\begin{array}{l}70 \\
63\end{array}$ & & & $\begin{array}{r}105 \\
99\end{array}$ & & 128.4 & 109.1 & 158.0 & 395.5 & $\begin{array}{c}400 \mathrm{~kg} \\
99 \%\end{array}$ \\
\hline $\begin{array}{l}5 \\
\text { 年 } \\
\text { 目 }\end{array}$ & $\begin{array}{l}2 \text { 年生苗 } \\
1 \text { 年生苗 }\end{array}$ & $\begin{array}{l}68.5 \\
76\end{array}$ & & & $\begin{array}{l}118.4 \\
117.3\end{array}$ & & 325.2 & 226.7 & 180.1 & 732.0 & $\begin{array}{r}1200 \mathrm{~kg} \\
60 \%\end{array}$ \\
\hline
\end{tabular}

\section{2 茶園管理の実態}

\section{(1.) 年次別投下労働時間}

定植当年より第 5 年目をでの $10 \mathrm{a}$ 当たり年次別投下労 働時間の概要恃表 5 のとおりであった。

第 1 年目は造園，定植関係の労務を伴 5 ので，年間投 下労㗢㭙間は $10 \mathbf{a}$ 当たり 210 時間を要したが，このうち 造園関係には実に 184.2 時間を要し，造園作業の省力あ るい忮術の向上はきわめて重要な問題であることを知 ることができた。特に定植作業は 3 月中下旬の限られた 数日間に，多数の人員を雇傭配置することは今後困難と なることが予測される。したがって，定植技術について は単に学務刘策とい5面ではなく，技術の向上という観 点から幅広く検討することが必要であると思われた。

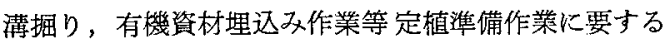
労力は造園関係労力の約 60 䒺机相当する 108 時間を要し ているので，この準備作業の作業体系とついても省力化 の面からの検討が必要と思われた。

第 1 年目管理作業特間は $10 \mathbf{a}$ 当たり 25.8 㭙間で，特に 過大な労力負担ではなかったが，これは除草体系の整備 に当を得た結果を具体的に立証し得たものと思われる。 それにしても除草関係労力は 1 年目の管理作業時間の55 \%と高い比率を示すことからみても重要作業の一つであ ることにはかわりはない。

第 2 年目以降の管理労力の中でも上記除草作業の比重 が最も高く（管理時間の約 $33 \%$ ）幼木茶園管理とは草と の戦いといら結果をまざまざと見せつけられるのである が，除草剤を利用すれば 10\%程度の省力化が可能になる という第 4 年目の経営結果に括惊示唆も得られた。
施肥作業につい以は，従来通りの手散き作業をそのま ま作業体系の中に織り込んだが，労㗢時間の構成比の中 では 20〜25\% と高い比率を占めること，さらには施肥勃 率を高めるための施肥法の合理化等を考感に入れるとす れば，施肥法の省力技術についても未解決の点が残され ているように思われた。

防除作業は幼木茶園用としての防除体系の中では， 1 〜 2 年目には粉剂む利雨したが, 第 3 年目以降は $30 \mathrm{~m}$ 拉 きに農道整備を実施してスワーススプレヤ利用の体系を とりこんた。防除作業の省力化は作業時間の絶対量の問 題よりも，むしろ組作業要員をきわめてきびしい防除適 期間中に確実に配置できるかが問題であるよ5に思われ た。

$10 \mathbf{a}$ 当たり管理労㗢特間の合計は 2 年目 91 時間， 3 年 目98時間， 4 年目 73 時間， 5 年目 48 時間と学働の省力化 は容易に獾得できることが明らかになったが，このため には農道や畑の長うね区画等の整備が必要であることは いうまでもない。

（2）年次別茶園育成費

定植当年から 5 年目までに要した茶園の直接投入費等 は表 6 のと打りであった。すなわち，経営的には 4 年目 から育成期間を脱することになるが，地代，建物施設等 が含まれていないので，実質的には 5 年目からと見なし た活 5が妥当である5。3年目までの淔接育成費用累 計，すなわ成園費は 104,929 円であった。年次別育成 費の中では，肥料費，萖刜費の増加が顕著である。これ は生育の増大に伴 5 自然増としての費用の投入である が, 結果的には，それが効率的であったか否かは検討の 
表 5 年次別投下労僖時間

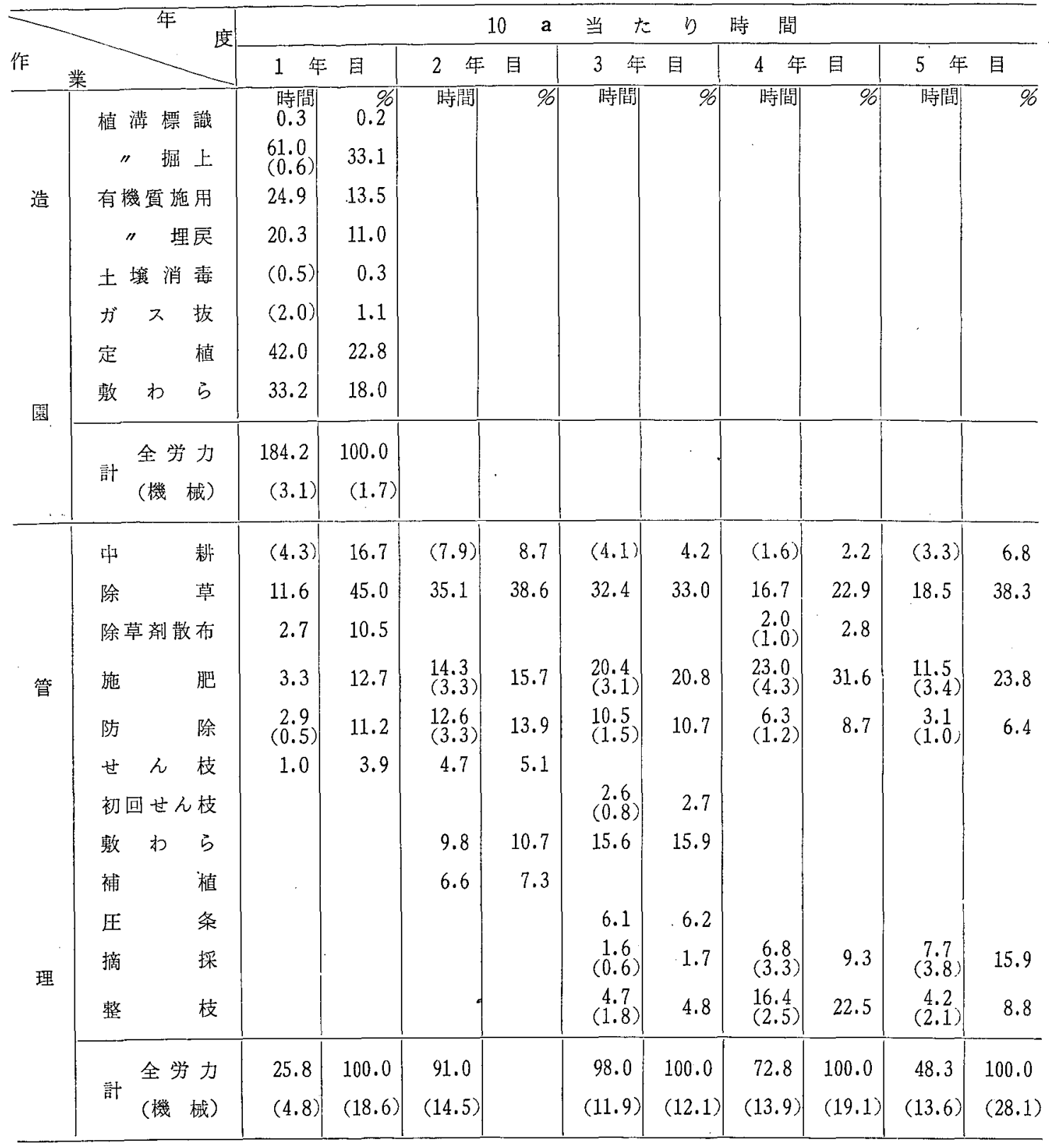

注：（）は機械利用時間

余地が大きい。

一方，生産については，年次別收量は 3 年目 $108.6 \mathrm{~kg}$, 4 年目 $395.5 \mathrm{~kg}, 5$ 年目 $732 \mathrm{~kg}$ であり，当初の期待収量 にくらべると $60 \%$ とい低生座にとどまったが，今後は さらに個別技術の整備による效率的茶園の造成が必要で
ある。そしてまた一力では，投入費用を節減する立場か らのみでなく，茶園の造成から積極的に増収を期待する 方向の中に高い生屡性が得られるるのと考えられる。こ のためには栽植密度を 2 倍程度 (2 条一 4 , 166本) にする ことが望屯しいと考学られる。 
表 610 a 当たりの育成費（ 5 ha 想定）

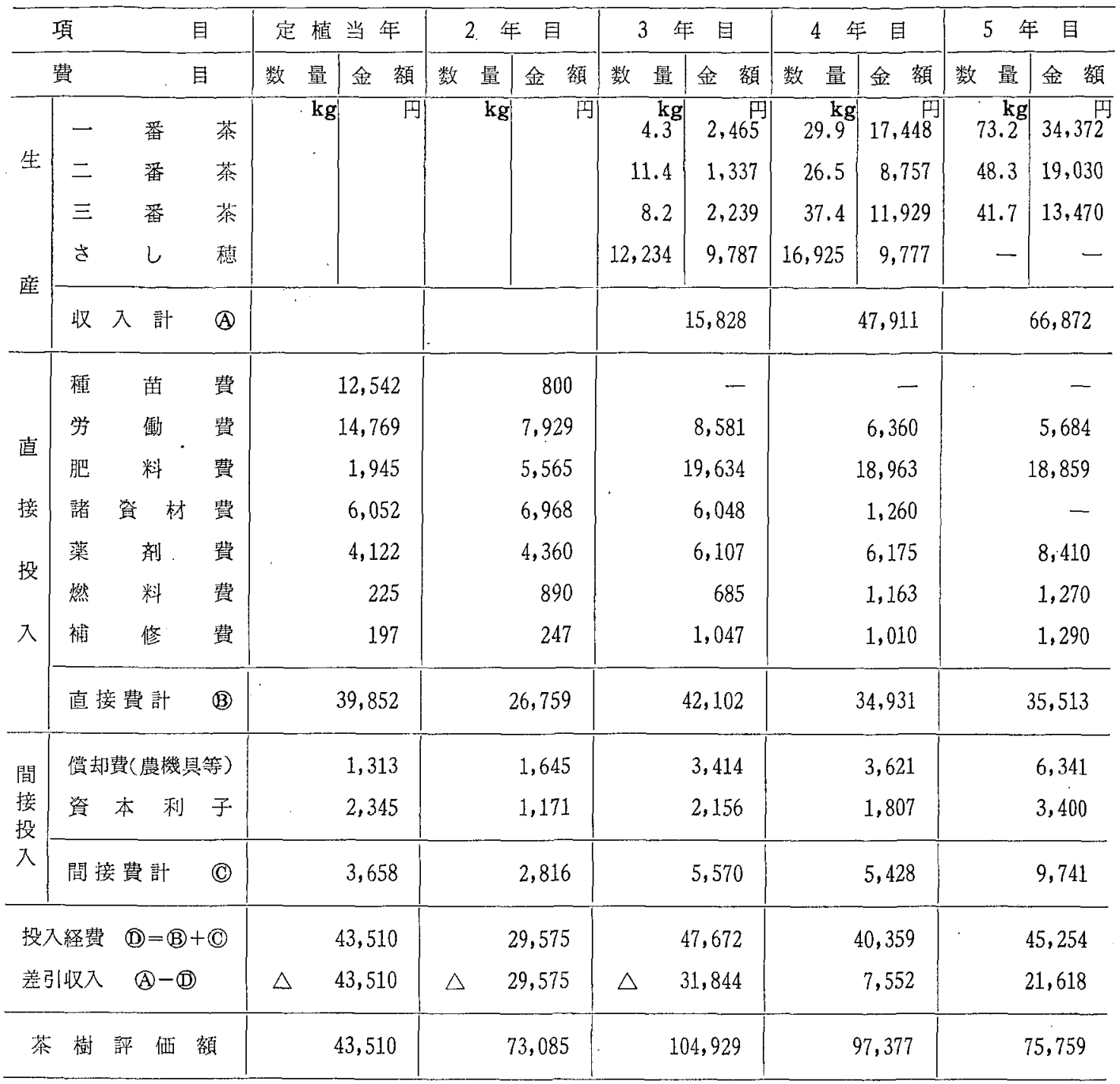

注：(1) ただし，建物施設，茶園の償却费初よび利子，地代、租税公課等は含まない。

(2) $\triangle$ 印は差引収入が負の場合を示す。

（3）生䈎加亡は共同工場において生暮 $\mathbf{k g}$ 当20円で零託加工し, 荒茶価格は経済連による競売価格によっ て算出した。

\section{3 定植等掘りの機械化}

従来の定植搏掘りは人力によるため多くの労力を要し ているが，有機物投入のためこの整㨄作業を機械化する 方法について調查した。

(1) 試歌力法

(ク）試験活場の区画と面稓

(1) 供試農業機械

フォードソンデキスター $35 \mathrm{ps}$

16インチプラウ

$\begin{array}{llll}\text { 高 さ } & 40 \mathrm{~cm} & \text { 全 長 } 115 \mathrm{~cm} \\ \text { 底 幅 } & 30 \mathrm{~cm} & \text { 土切円板 } 39 \mathrm{~cm} \\ \text { 刃 } & \text { 長 } & 50 \mathrm{~cm} & \end{array}$

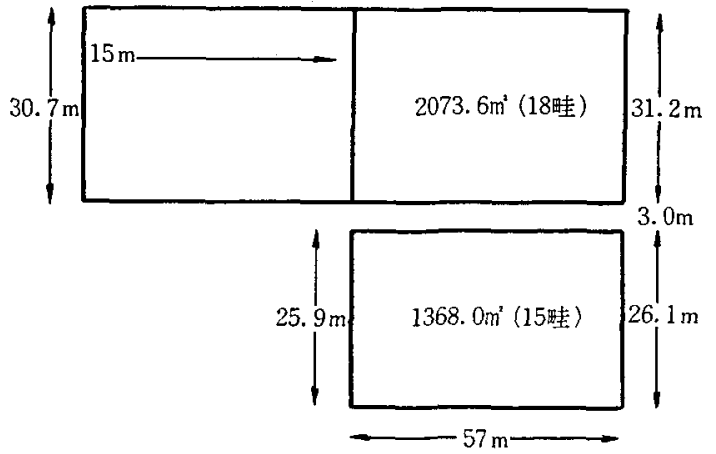

面積 34.4 a

図 1 䟼験晹 


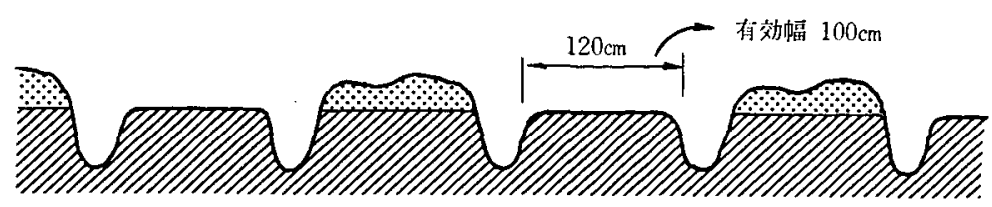

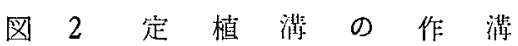

(六) 有機物 $10 \mathrm{a}$ 当たり約 $2,000 \mathrm{~kg}$ (枯草十溉肥)

(I) 作 業力 法

植淟掘り

炕地の雨側に定植溝位置の標準棒（竹）を打ち込み， それにそって 1 う扫 1 往復耕起して通った。

(2) 調 查 結 果.

(乃) 作 業精 度

トラクタにより作溝した定植溝について, 図 3 の部位 を調查した結果は表7のと技りであった。すなわり，耕 起開始時には枕地よりブラウを梁くしていくため抌地に $242 \mathrm{~cm}$ の不耕起部分が認められるが，往復耕を行な5の で，耧起終了㭙では枕地の不耕起部分は $135 \mathrm{~cm}$ に縮少さ れた。定植瑇の上幅はプラウですき掘るとき土䱋がずり 落ちて轾く覆われる見か外上の部分を仮として表わすと これが $50.5 \mathrm{~cm}$ ，真の有効幅は $56.5 \mathrm{~cm}$ となる。一方，底 幅は仮で $25.5 \mathrm{~cm}$, 真で $29.5 \mathrm{~cm}$ となった。定植溝の深さ では仮で $19.5 \mathrm{~cm}$, 真で $26.5 \mathrm{~cm}$ となり, 有機物（枯草 十既肥）約 $2000 \mathrm{~kg}$ の施用に对して十分な樑さおよび幅

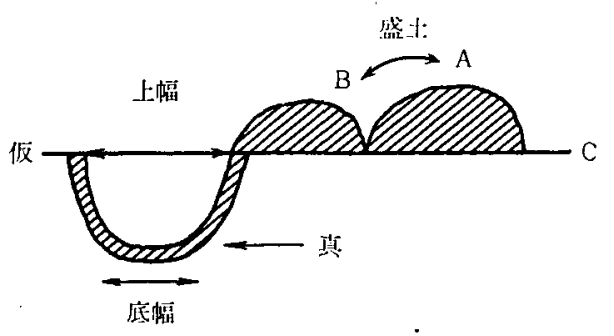

図 3 定植临の調查部位

を示し，笑際に有機物施用時にるなんら支障はみられな かった。しかし，枕地の不耕起部分や定植溝のプラウに よる土塞の耕起が不十分な面がみられ，これらの人力に よる整理崡りの必要があった。

トラシタの定植溝掘りにおける直進度を定植溝の中心

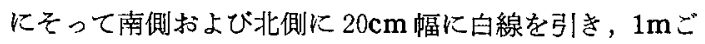
とに心から定植溝の片側幅を測定した結果は表 8 のとお りである。すなわち，トラクターの直進は $22.5 \mathrm{~cm} \pm 1.09$ 表 7 定植雀 の 規格

\begin{tabular}{|c|c|c|c|c|c|c|c|c|c|}
\hline \multicolumn{4}{|c|}{ 掬 } & \multicolumn{2}{|c|}{ 量 } & \multirow{2}{*}{ 盛 } & \multirow{2}{*}{ 土 } & \multirow{2}{*}{\multicolumn{2}{|c|}{ 枕地の不耕起距離 }} \\
\hline t. & 幅 $(\mathbf{c m})$ & 底 & 幅 $(\mathrm{cm})$ & 深 & $さ(\mathrm{~cm})$ & & & & \\
\hline 仮 & 真 & 仮 & 真 & 仮 & 真 & $A-C$ & $18 \mathrm{~cm}$ & 耕起開始 & $242 \mathrm{~cm}$ \\
\hline 50.5 & 56.5 & 25.5 & 29.5 & 19.5 & 26.5 & $B-C$ & 7 & 耕起終了 & 135 \\
\hline
\end{tabular}

表 8 トラクタ一直進度

\begin{tabular}{|c|c|c|c|c|c|c|c|}
\hline 位 置 & 心 - 南 & 位 & 心 - 南 & 位 & 心 - 北 & 置 & 心 一 北 \\
\hline $1^{\mathrm{m}}$ & $21.5^{\mathrm{cm}}$ & ${ }_{11}^{\mathrm{m}}$ & 29.5 & $1^{\mathrm{m}}$ & $\begin{array}{c}\mathbf{c m} \\
23.5\end{array}$ & ${ }_{11}^{\mathrm{m}}$ & $21.0^{\mathrm{cm}}$ \\
\hline 2 & 25.5 & 12 & 29.0 & 2 & 23.0 & 12 & 22.0 \\
\hline 3 & 30.0 & 13 & 29.0 & 3 & 21.0 & 13 & 21.0 \\
\hline 4 & 30.0 & 14 & 26.5 & 4 & 21.0 & 14 & 24.0 \\
\hline 5 & 27.0 & 15 & 24.0 & 5 & 21.0 & 15 & 25.5 \\
\hline 6 & 29.0 & 16 & 23.5 & 6 & 23.5 & 16 & 25.5 \\
\hline 7 & 30.0 & 17 & 26.0 & 7 & 22.0 & 17 & 25.5 \\
\hline 8 & 29.0 & 18 & 24.5 & 8 & 23.0 & 18 & 25.5 \\
\hline 9 & 26.0 & 19 & 28.5 & 9 & 23.0 & 19 & 19.5 \\
\hline 10 & 29.5 & 20 & 24.5 & 10 & 24.0 & 20 & 25.0 \\
\hline 平 均 & $27.7 \pm 2.62$ & & $26.5 \pm 2.21$ & & $22.5 \pm 1.09$ & & $23.4 \pm 2.21$ \\
\hline
\end{tabular}


$\mathrm{cm} \sim 27.7 \mathrm{~cm} \pm 2.62 \mathrm{~cm}$ の䇺囲にあっては，湾添一直線に 進行し蛇行は認められなかった。

(1) 機械による省力化

定植满の機械作業を人力と対比したのが表 9 である。 機械による開園に要した時間は $10 \mathbf{a}$ 当たり 4,755 分で。
その5ち定植溝据りは184 分となり全作業時閒の $10.2 \%$ であった。また，これは人力による場合の作業時間 3,693 分に対しわずかに $13.1 \%$ に過ぎず，大幅に省力化するこ とができた。

表 9 作業別労业時間（分/10 a )

\begin{tabular}{|c|c|c|c|c|c|c|}
\hline 区 別 & 人 & 力 & & 械 & 業 & \\
\hline 作業別 項 目 & 作業時間 & 種 類 & 作業時間 & 種 & 類 & 人力対比 \\
\hline 植 溝 標 識 & $19^{3}$ & \multirow[b]{2}{*}{$\begin{array}{l}\text { 培土 板 } \\
\text { スコップ }\end{array}$} & $604^{5}$ & \multirow{2}{*}{\multicolumn{2}{|c|}{$\begin{array}{l}\text { フォードソンデキスタ16インチプラウ } \\
\text { スコップ }\end{array}$}} & - \\
\hline 植 清 掘 上 & 3,693 & & 484 & & & 13.1 \\
\hline 有機質施用 & 1,491 & $乇 ッ \sqsupset$ & 3,482 & \multicolumn{2}{|c|}{ 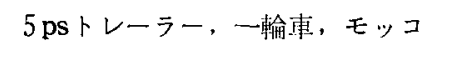 } & 233.5 \\
\hline 有機斦埋戻 & 1,291 & 三ッ鏩 & 185 & \multicolumn{2}{|c|}{$5 \mathrm{ps} 70$ ラロローター } & 15.2 \\
\hline 計 & 6,494 & & 4,755 & & 73.2 \\
\hline
\end{tabular}

\section{4 株元雑草の許容限界と除草対策}

幼木期代打る管理作業の中で，除草作業は大きい比 重を占めている。したがって，株元．5ね間の雑草制御 は幼木茶園管理の生産性向上にも結びつくものと考兄ら れる。このよ5な観点から，5ね間拉よび株元雑草の幼 茶樹におよ注寸影留上その除草方法について，株元の雑 草発生より20日，30日，40日，50日周期て除草処理を行 ない秋季に批ける奻茶樹の生育を調査した。また，万ね
間の機珹除草の作業については雑草の草丈 $5 \mathrm{~cm}, 10 \mathrm{~cm}$,

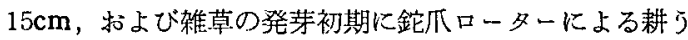
儿除草の可否を試験した。これらの結果は表10１3のと 抢りである。すなわち，表10のごとく雑草は各区とも 6 月中旬から 8 月下旬にかけ繁茂し草量は多かった。処 理時における草量は生育期閒の短かい20日 周期区が最も 少なく，次いで30日，40日，50日と処理期間の長いほど 多かった。したがって処理当たりの除草㭙間は草量およ

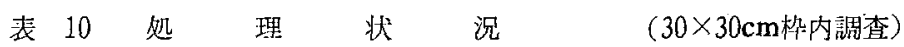

\begin{tabular}{|c|c|c|c|c|c|c|c|c|c|c|c|c|c|c|c|}
\hline $20 \quad \mathrm{H}$ & 周 & 期 区 & & & 30 日 周 & 期 区 & & & 10 日周 & 期 区 & & & 50 日 & 圆 期 & \\
\hline 処理 日 & 草生: & 状況 & \begin{tabular}{|l|} 
除莫力 \\
学力
\end{tabular} & 処理日 & 草生壮 & & $\begin{array}{l}\text { 除草 } \\
\text { 労力 }\end{array}$ & 処理日 & 草生. & 状況 & $\begin{array}{l}\text { 除草 } \\
\text { 学力 }\end{array}$ & 処理日 & 草生 & 状況 & $\begin{array}{l}\text { 除草 } \\
\text { 労力 }\end{array}$ \\
\hline $\begin{array}{c}\text { 月 } 日 \\
4.13\end{array}$ & $\begin{array}{r}\mathbf{g} \\
5.3\end{array}$ & $\begin{array}{r}\text { 本 } \\
547\end{array}$ & $\begin{array}{r}\mid \text { 分/10a } \\
458\end{array}$ & 月 日 & $\begin{array}{r}\mathbf{g} \\
7.0\end{array}$ & $\begin{array}{r}-A \\
621\end{array}$ & $\begin{array}{r}10 \mathrm{a} \\
666\end{array}$ & 月日 & $\mathrm{g}$ & & 分/10a & 月 日 & $\mathbf{g}$ & 本 & 分/10a \\
\hline 5. 2 & 4.0 & 445 & 2,042 & - & & & & 5. 2 & 25.7 & 569 & 93,833 & 5. 9 & 109.0 & 686 & 2,792 \\
\hline 5. 20 & 8.3 & 459 & 1,875 & 5. 20 & 43.3 & 595 & 2,500 & - & & & & - & & & \\
\hline 6. 12 & 10.0 & 450 & 7,500 & 6. 19 & 163.0 & 484 & 6,041 & 6.10 & 226.0 & 434 & 5,416 & - & & & \\
\hline 6. 26 & 4.7 & 97 & 2,500 & - & & & & - & & & & 6.26 & 512.0 & 387 & 6,666 \\
\hline 7. 16 & 13.0 & 128 & 2,500 & 7. 16 & 14.5 & 150 & 3,458 & 7. 16 & 149.0 & 174 & 4,375 & - & & & \\
\hline 8. 8 & 94.1 & 103 & 2,621 & 8. 15 & 212.0 & 74 & 2,500 & - & & & & 8.15 & 353.0 & .77 & 7,339 \\
\hline 8. 28 & 3.3 & 65 & 1,872 & - & & & & 8. 26 & 292.9 & 39 & 4,461 & - & & & \\
\hline 9. 16 & 6.6 & 31 & 1,248 & 9. 16 & 72.0 & 52 & 1,914 & - & & & & - & & & \\
\hline 10. 6 & 2.0 & 50 & 1,082 & 10. 15 & 6.1 & 72 & 1,789 & 10. 7 & 28.5 & 38 & 1,830 & 10.7 & 180.0 & 56 & 4,160 \\
\hline 10. 26 & 13.0 & 61 & 3,328 & - & & & & & & & & - & & & \\
\hline 合 計 & 164.3 & 2,436 & 27,025 & & $|517.9|$ & 2,048 & 3,868 & & 721.2 & 1,254 & 19,965 & & $|1154.9|$ & 1,206 & 20,957 \\
\hline 均 & 14.9 & 221 & 2,456 & & 74.0 & 293 & 2,695 & & $\mid 144.2$ & 251 & 3,993 & & 289.0 & 302 & 5,239 \\
\hline 除草回数 & & 11 & & & & 7 & & & & 5 & & & & 4 & \\
\hline $\begin{array}{l}\text { 䞗理時の草丈 } \\
(\mathrm{cm}) \\
\text { 処理時の葉数 } \\
\text { (枚) }\end{array}$ & & $\begin{array}{r}0.5 \sim 2 \\
1 \sim 2\end{array}$ & & & & $\begin{array}{r}0.4 \sim 4 \\
2 \sim 7\end{array}$ & & & & $\begin{array}{r}0.5 \sim 6 \\
2 \sim 6\end{array}$ & & & & $\begin{array}{l}5 \sim 70 \\
2 \sim 54\end{array}$ & \\
\hline
\end{tabular}


表 11 秋季飞お打る生育状. 況

(昭和 43 年 10 月 30 日 1 区10株 2 反復)

\begin{tabular}{|c|c|c|c|c|c|c|c|c|c|}
\hline 項 目 & 区 & 20 & 日 区 & 30 & 日 & 40 & 日 & 50 & 日 \\
\hline 樹 & 高 $(\mathrm{cm})$ & & 46 & & 48 & & 44 & & 44 \\
\hline 株 張 & $b(\mathrm{~cm})$ & & 25 & & 25 & & 22 & & 18 \\
\hline 幹 & 径 $(\mathrm{mm})$ & & 6.4 & & 6.4 & & 5.9 & & 5.9 \\
\hline 同＼cjkstart指 & 数 & & - & & 100 & & 92.2 & & 92.2 \\
\hline 分 枝 & 数 (本) & & 12 & & 14 & & 16 & & 12 \\
\hline 同＼cjkstart指 & 数 & & - & & 116.7 & & 133.3 & & 100.0 \\
\hline 案 & 数 (枚) & & 154 & & 176 & & 167 & & 139 \\
\hline 同 指 & 数 & & - & & 114.3 & & 108.4 & & 90.3 \\
\hline \multicolumn{2}{|c|}{ 主要因子の指数合計 } & & 一 & & 331 & & 333.9 & & 282.5 \\
\hline \multirow{2}{*}{$\begin{array}{l}\text { 地下 } 15 \mathrm{~cm} \\
\text { 小全㝘素 } \\
\text { 含量 }(\%) \text { ) }\end{array}$} & 5月15日 & & 0.615 & & 0.672 & & 0.668 & & 0.615 \\
\hline & 12月 3 日 & & 0.462 & & 0.467 & & 0.467 & & 0.457 \\
\hline
\end{tabular}

表 12 処理時に括ける受光度（3区平均）

\begin{tabular}{|c|c|c|c|c|}
\hline 項 $\quad$ 目 & 20 日 区 & 30 日 区 & 日 区 & 50 \\
\hline 測 定 月 日 & 8. 28 & 8. 15 & 8. 26 & 8. 15 \\
\hline 露 天受光度 & 8 & 9 & 8 & 9 \\
\hline 丈 $(\mathrm{cm})$ & $0.5 \sim 2.5$ & $7 \sim 45$ & $6 \sim 60$ & $5 \sim 70$ \\
\hline 地 上 $5 \mathrm{~cm}$ & 8 & 0 & 0 & 0 \\
\hline 地 上 $15 \mathrm{~cm}$ & 8 & 3 & 0.8 & 0.7 \\
\hline 地 上 $30 \mathrm{~cm}$ & 8 & 6 & 2 & 1.7 \\
\hline 地上 $45 \mathrm{~cm}$ & 8 & 8 & 5 & - \\
\hline 地 上 $60 \mathrm{~cm}$ & 8 & 8 & 8 & 3.7 \\
\hline
\end{tabular}

調查方法：Coronet B 露出計で幼茶樹の外周を地際より $5 \mathrm{~cm}, 15 \mathrm{~cm}, 30 \mathrm{~cm}, 45 \mathrm{~cm}$ に区分して測定した。

び除草周期の長くなるほど多い傾向にあった。秋季にお ける幼茶樹の生㻆心表11のと括りで樹高，幹径，株張り 等に影響がみられ，40日および50日区が劣った。また， 受光度を調查した結果は表120と扣りで，雑草の草丈の 高くなる区，すなわち，40日，50日区に批て奻茶楜へ の透光度は低下し，幼茶樹への悪影響が認められた。こ れらのここから㧣元雑草の（主要草種メヒシバ）の多少 は幼茶樹期間，特に定植当年には生充に大きく影響する ので，30日目でこれが $820 \mathrm{~g} / \mathrm{m}^{2}$ 以上の草生を許すことは できないと思われた。したがって，株元除草は雑草の発 生をみてから30日以内に行な5ことが必要こ思われた。

一方，亏れ間の雑草と処理状況を示したのが表13であ る。発芽初期処理の雑草は耕 5 んによって十分埋没し,
耕 万んピッキむ速いので $10 \mathrm{a}$ 当たり平均32分で好理でき たが，雑草は高温多湿の期間中に多発するので，耕 うん 数は多かった。な拈，草丈 $5 \mathrm{~cm} ， 10 \mathrm{~cm}$ の処理において は耕 万ん除草の実施上からはなんら支障なかったが，草 丈 $15 \mathrm{~cm}$ では7〜8月の雑草繁茂が著しい時期にはロー ターに巻き付きが生じた。これらのことから，盛夏期の 株元雑草は 20〜30日周期で行なうことが必要である。た だし，株元に敭草されている場合には，いくらかの期間 延長は可能であろ 万。また，5ね間は雑草の草丈 10〜15 $\mathrm{cm}$ 基準とすればローターによる処理適期期間は25〜 30日あることになるので，これらを適宜に組み合わせる ベきであろ5。 
表 13 う构間の雑草とその処理状況

\begin{tabular}{|c|c|c|c|c|c|c|c|c|c|c|c|c|c|}
\hline \multirow{2}{*}{\multicolumn{2}{|c|}{ 項 目 }} & \multicolumn{2}{|c|}{ 発 } & 泺 & 紬 & \multicolumn{3}{|c|}{ 処 } & \multicolumn{5}{|c|}{ 草丈 $5 \mathrm{~cm}$ 処 理 } \\
\hline & & 1 & 2 & 3 & 4 & 5 & 6 & 7 & 1 & (2) & 3 & (4) & 5 \\
\hline \multirow{2}{*}{\multicolumn{2}{|c|}{ 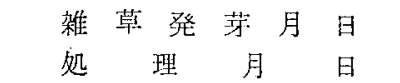 }} & 4.6 & 5. 1 & 5.17 & 6. 1 & 6.19 & 7.10 & 8. & .6 & 5.17 & 6. 1 & 7.10 & 7.2 \\
\hline & & 4.8 & 5.8 & 5.21 & 6.6 & 6.19 & 7.16 & 18.8 & 5.8 & 5.21 & .19 & 7.16 & 8. \\
\hline \multicolumn{2}{|c|}{ 処 理 周 期 (期間) } & - & 3 & 13 & & 13 & 27 & & - & 13 & 29 & 27 & 23 \\
\hline \multirow{2}{*}{\multicolumn{2}{|c|}{$\begin{array}{lccc}\text { 発 芽 } & \text { 日 } & \text { 数 } & \text { （日） } \\
\text { 発芽 } \rightarrow \text { 処 理 } \text { 日 数 } & (\text { (日) }\end{array}$}} & & 2. & 9 & & 13 & 2 & & - & c & & 21. & 10 \\
\hline & & 2 & 7 & 4 & 5 & 0 & 6 & & 32 & 4 & 18 & 6 & 13 \\
\hline \multirow{3}{*}{$\begin{array}{l}\text { 処草 } \\
\text { 理 } \\
\text { 時 } \\
\text { の生 }\end{array}$} & \multirow{3}{*}{ 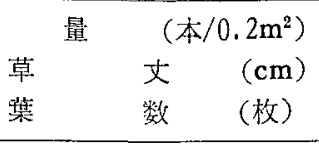 } & 124 & 24 & 94 & 80 & 116 & 59 & 24 & 76 & 299 & 238 & 223 & 38 \\
\hline & & 1 & $1-$ & 1 & $\sim 3$ & 1 & 1 & $1 \sim 8$ & $1 \sim$ & 1 & 5 & $1 \sim 20$ & $1 \sim$ \\
\hline & & 1 & 1 & 1 & 3 & $1 \sim 2$ & $2 \sim 4$ & 8 & $1 \sim 7$ & 1 & -3 & $2 \sim 20$ & 1 - \\
\hline \multirow{6}{*}{\multicolumn{2}{|c|}{ 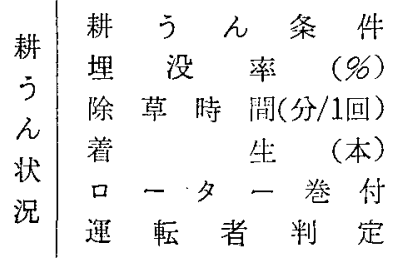 }} & & & & & & & & & & & & 氏- \\
\hline & & 90 & 92 & 93 & 93 & 92 & 82 & 100 & 88 & 86 & 87 & 92 & 10 \\
\hline & & 2 & 3 & 3 & 3 & 3 & 6 & 3 & 0 & 3 & 6 & 13 & \\
\hline & & - & - & - & - & - & - & - & - & - & - & 2 & \\
\hline & & 無 & 無 & 無 & 無 & 無 & 無 & 䥻 & 無 & 䙲 & 侮 & 少 & 無 \\
\hline & & 0 & 0 & 0 & 0 & 0 & 0 & 0 & 0 & 0 & 0 & 0 & $\triangle$ \\
\hline \multirow{2}{*}{\multicolumn{2}{|c|}{$\begin{array}{l}\text { 株元処理時間 (分/10a) } \\
\text { う的間処理時間 (分/10a) }\end{array}$}} & -1 & 296 & & 391 & & & 1334 & 826 & & 391 & & 133 \\
\hline & & 24 & 28 & 26 & 30 & 32 & 55 & 29 & 54 & 27 & 57 & 114 & 5 \\
\hline
\end{tabular}

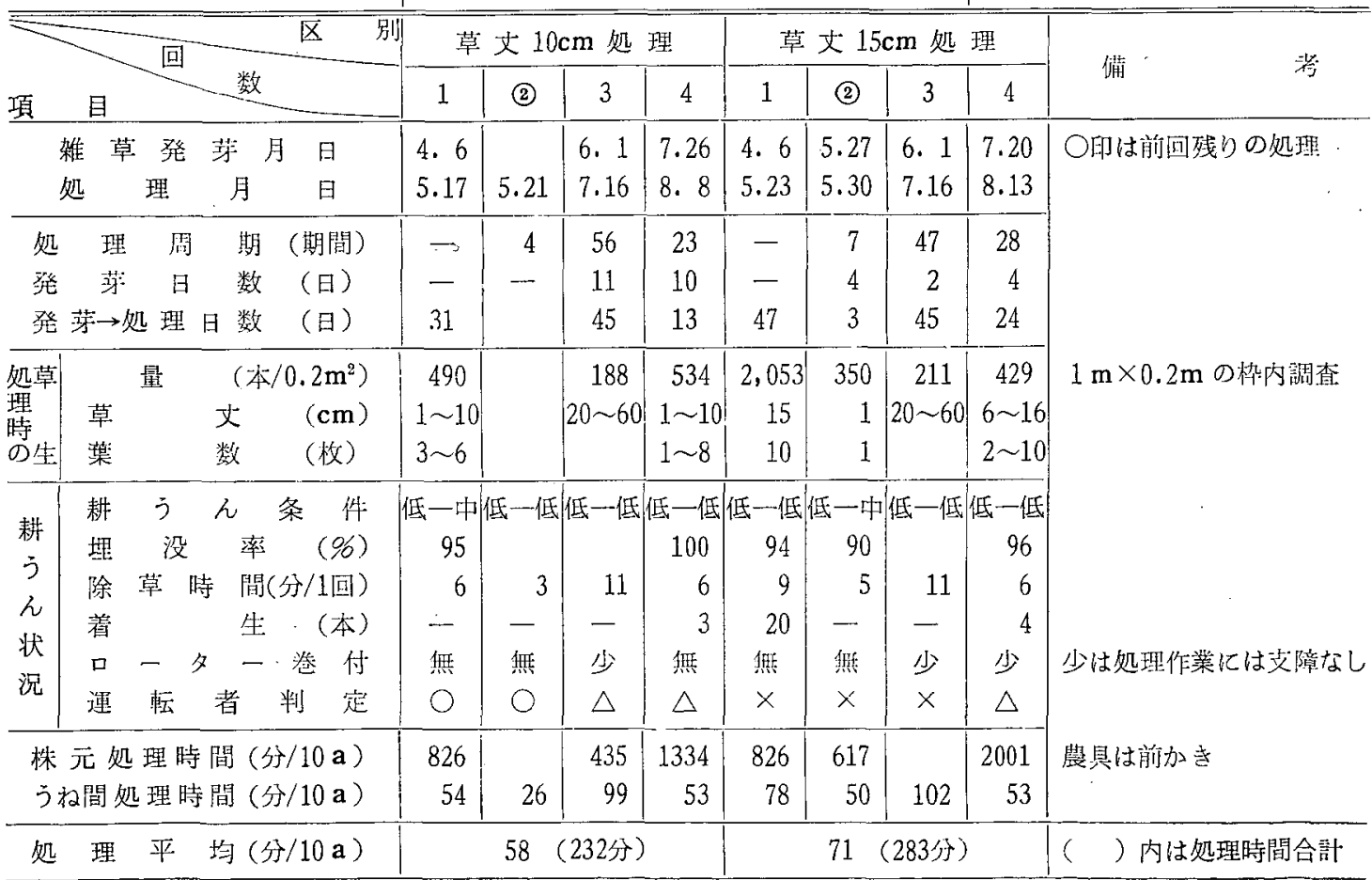

\section{5 病害虫防除の省力化}

幼木茶園の防除作業には従来 $5 \sim 6$ 人程度の組作業人 員を必要としていたが，労働事情の悪化しつつある現在 ではこの組作業人員の絶対数をできるだけ少なくする必 要がある。このよ な観点から組作業人員を少なくする
オ法について検討した。すなわち，スワーススプレーヤ を動力噴蓩機と比較調査した。その結果は表14のとおり であった。スワーススプレーヤの稼動時間は動力噴雼機 の $41.8 \%$ ，末た，労働持間では $32.2 \%$ となり，動力噴霧 機より大幅な省力が双られた。 
表 14 防除の省力方法調疽

\begin{tabular}{|c|c|c|c|c|c|c|c|c|c|c|c|c|}
\hline \multirow[b]{3}{*}{ 回 } & \multicolumn{5}{|c|}{ LP750（5ps）動噴（高正ポンプ） } & \multicolumn{5}{|c|}{ スワーススプレーヤ（10ps） } & \multicolumn{2}{|c|}{$\begin{array}{l}\text { 動喷に対する } \\
\text { 比率 }(\%) \\
\end{array}$} \\
\hline & \multicolumn{2}{|c|}{ 機械作業 } & \multicolumn{3}{|c|}{ 労 働 時 間 } & \multicolumn{2}{|c|}{ 機械 作 業 } & \multicolumn{3}{|c|}{ 労 働 時 間 } & 機 械 & 労働時間 \\
\hline & 使用時間 & 組作業 & 男 & 女 & 計 & |使用時間 & \begin{tabular}{|l|l} 
組作對 \\
\end{tabular} & 男 & 贡 & 計 & - & - \\
\hline 1 & $62^{\text {㸮 }}$ & $5^{\text {人 }}$ & $62^{\prime \prime}$ & $248^{\text {分 }}$ & 310 & $26^{\text {分 }}$ & $3^{\prime}$ & $26^{\prime \prime}$ & $52^{\text {3) }}$ & $78^{\text {Sग }}$ & - & - \\
\hline 2 & 70 & 4 & 70 & 210 & 280 & 29 & 4 & 29 & 84 & 113 & - & - \\
\hline 計 & 132 & & 132 & 458 & 590 & 55 & & 55 & 136 & 190 & - & - \\
\hline 平均 & 66 & & & & 295 & 27.5 & & & & 95 & 41.8 & 32.2 \\
\hline
\end{tabular}

\section{4 考察}

5 年間にわたる奻木茶園管理作業の省力化に関する実 証試験を行なったが，この期間に摘出された問題点を解 決するため実施した個別技術対策試験は，とりもな拉さ ず新しい妨木茶園管理作業体系を確立するた放に必要な 技術資料を提供するものにほかならない。したがって， ここでは本試験設計時に作成した前記管理技術試案をよ り実情に即するように補完整備すること自体が考察のす ベてである。

基盤整備が省力機械化の前提であるので，茶園の区画 は30 a $(100 \mathrm{~m} \times 30 \mathrm{~m})$ とし，農道（猐地）を整えた $5 \mathrm{ha}$ 規模の茶園を想定して管理作業機械条件を考虑した。こ のような条件下で改めて体系化のための作業指標として 試算を立てると $1 \mathrm{ha}$ 当たり年間所要労㗢時間の 合計で
定植当年 989.7 時間， 2 年目 621.6 㭙間， 3 年目 723.1 特 間， 4 年目 699.8 時間， 5 年目 478.2 時間までの省力化恃 可能であると判断された。しかし，これは単に個々の管 理作業時間の合計であり，実作業管理体系の中での労儌 時間ではない。作業の準備や整備等のための所要時閒が 上記に加味されなければならないことはいうまですな w。

なお，この体系化のための指標についての評価は体系 化の中に装備されるべき個別技術の改善の集皘としての 茶園の収益性の上に理解されるはずである。収量調查の

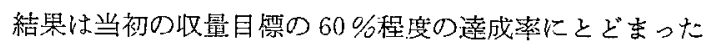
ので，この指標の中で恃に栽植密度は本試験設計の 2 倍の泌粗法を扱用することにして定植 5 年目には年間収 量 $1,200 \mathrm{~kg}$ は確保でさる技術として配留した。

表 15 農業機械装備

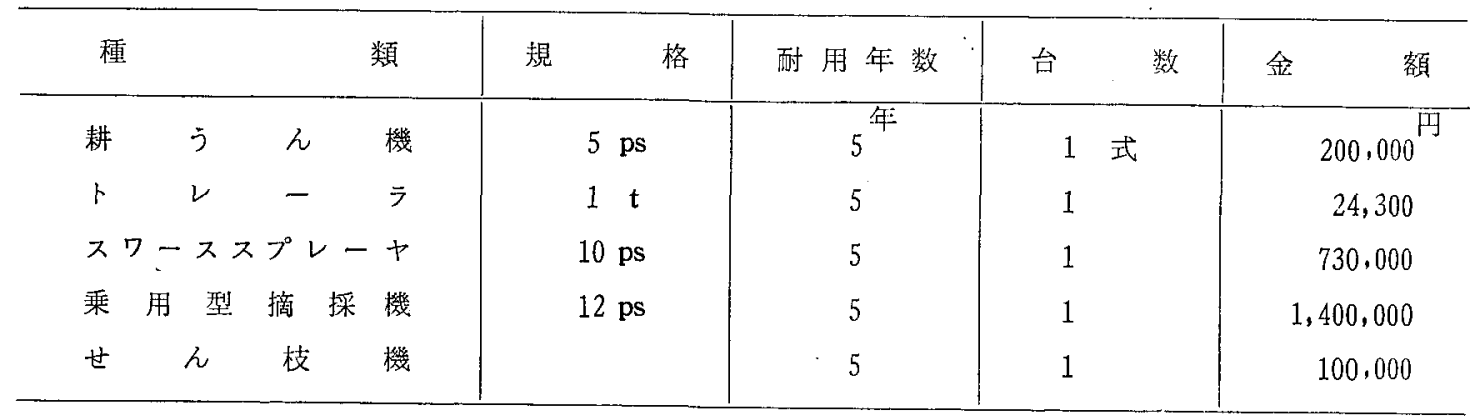

注：トラクタ 35ps は貨借するものとする。 
第 37 号 $\left(\begin{array}{llll}1 & 9 & 7 & 2\end{array}\right)$

表 16 定植当年

\begin{tabular}{|c|c|c|c|c|c|c|c|c|}
\hline \multirow[b]{2}{*}{ 作業名 } & \multirow{3}{*}{$\begin{array}{c}\text { 作 業 方 法 } \\
\text { プラウで深さ約 } 25 \mathrm{~cm} \text { 作 } \\
\text { 条し, 有機質資材 } 2,000 \\
\mathrm{~kg} \text { を施し覆土整地する。 }\end{array}$} & \multirow{3}{*}{ 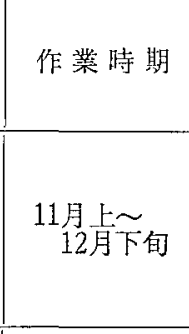 } & \multirow{3}{*}{$\frac{\text { 労働手段 }}{\text { 機 }}$} & \multirow{3}{*}{$\frac{\text { 作業機名 }}{\text { ドラクタ }}$} & \multirow{2}{*}{\multicolumn{3}{|c|}{ 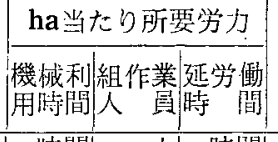 }} & \multirow[b]{3}{*}{ 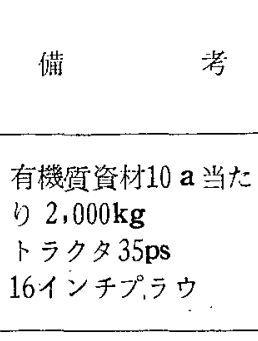 } \\
\hline & & & & & & & & \\
\hline 定 & & & & & $\begin{array}{r}\text { 特間 } \\
8.1\end{array}$ & 1 人 & $\begin{array}{l}\text { 時間 } \\
79.5\end{array}$ & \\
\hline 倩準 $\begin{array}{l}\text { 土 } \\
\text { 壤 } \\
\text { 消 } \\
\text { 毒 }\end{array}$ & $\begin{array}{l}30 \mathrm{~cm} \text { 間隔の } 2 \text { 条で深さ } \\
15 \mathrm{~cm} \text { 注入. }\end{array}$ & $\begin{array}{l}2 \text { 月上 } \\
3 \text { 月下白 }\end{array}$ & 機 械 & 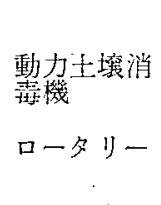 & 5.3 & 1 & 26.0 & 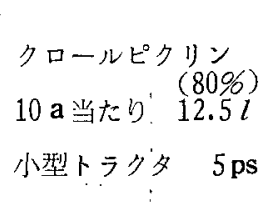 \\
\hline 定 & 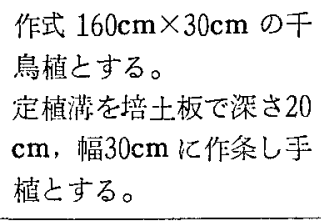 & 3 月中芐旬 & $\begin{array}{ll}\text { 機 械 } \\
\text { 人 } \\
\text { 人 }\end{array}$ & 墥 上: 板 & 5.1 & 1 & 420 & $\begin{array}{l}10 \text { a 当たり涐植本数 } \\
4,166 \text { 本 } \\
\text { 小型トラク夕 } 5 \text { ps }\end{array}$ \\
\hline $\begin{array}{l}\text { 敭 } \\
\text { 草 }\end{array}$ & $\begin{array}{l}\text { 株元陑側の } 30 \mathrm{~cm} \text { 幅位に } \\
\text { 滶わらを行なう。 }\end{array}$ & & 人 力 & & & & 156 & $10 \mathrm{a}$ 当たり $1.000 \mathrm{~kg}$ \\
\hline 肥 & $\begin{array}{l}\text { 株元に施肥し、ロータリ } \\
\text { 一で耕うんする。 }\end{array}$ & $\begin{array}{l}4 \text { 月下旬 } \\
5 \text { 月下旬 } \\
6 \text { 月下白 } \\
7 \text { 月下旬 }\end{array}$ & $\begin{array}{ll}\text { 機械 } \\
\text { 人 } \\
\text { 人 }\end{array}$ & ロータリー & 20.0 & & 33.2 & $\begin{array}{c}\text { 人力散后 } \\
\text { 小型トラクタ } \\
\vdots \\
\vdots\end{array}$ \\
\hline $\begin{array}{l}\text { 新 } \\
j \\
\text { 之 } \\
\text { 除 } \\
\text { 草 }\end{array}$ & $\begin{array}{l}\text { う补閒はロータリーで耕 } \\
\text { うんし，敷わら際は除草 } \\
\text { 剂优用 }\end{array}$ & 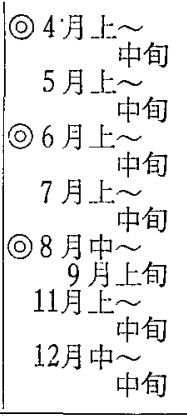 & 機 械。 & $\begin{array}{l}\text { ロータリー } \\
\text { 動力噴笨機 }\end{array}$ & $\begin{array}{l}35 \\
35\end{array}$ & $\begin{array}{l}1 \\
2\end{array}$ & $\begin{array}{l}35 \\
70\end{array}$ & $\begin{array}{l}\text { (0印の耕うん除䓬の } \\
\text { 際, 袾元の手拢作業 } \\
\text { を突施する。 } \\
\text { 小型トラクタ } 5 \mathrm{ps}\end{array}$ \\
\hline $\begin{array}{l}\text { 病 } \\
\text { 書 } \\
\text { 虫 } \\
\text { 防 } \\
\text { 除 }\end{array}$ & $\begin{array}{l}\text { 噴口はスワーススプレヤ } \\
\text { 用庆幅散布ノズルを使用 } \\
\text { する。 }\end{array}$ & 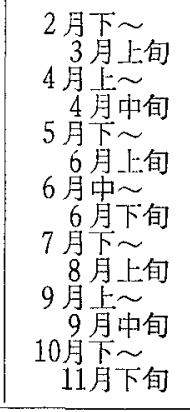 & 機 旅 & $\begin{array}{l}\text { ㅈワースス } \\
\exists レ-p\end{array}$ & 45 & 2 & 90 & - \\
\hline 計 & & & & & 153.5 & & 989.7 & \\
\hline
\end{tabular}


表 17 定植 $2 \sim 3$ 年 目

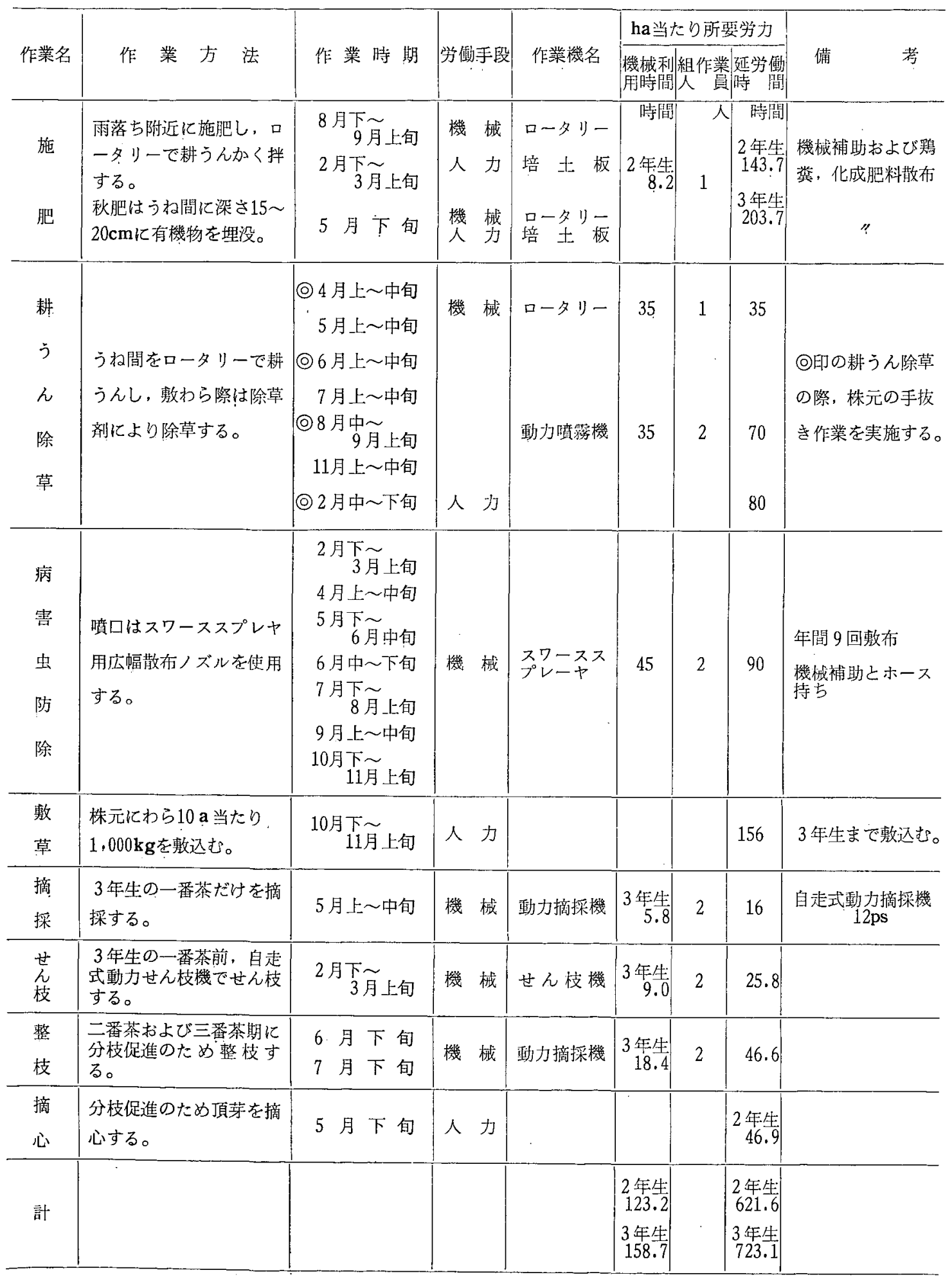


表 18 定植 $4 \sim 5$ 年目

\begin{tabular}{|c|c|c|c|c|c|c|c|c|}
\hline \multirow[b]{2}{*}{ 作業名 } & \multirow[b]{2}{*}{ 作 業 开 法 } & \multirow[b]{2}{*}{ 作業時期 } & \multirow[b]{2}{*}{ 学働手段 } & \multirow[b]{2}{*}{ 作業機名 } & \multicolumn{3}{|c|}{ ha当たり所要労㗢 } & \multirow[b]{2}{*}{ 備 } \\
\hline & & & & & $\begin{array}{l}\text { 機械利 } \\
\text { 型時閏間 }\end{array}$ & $\mathrm{N}^{\text {县作業 }}$ & 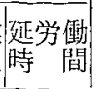 & \\
\hline 施 & $\begin{array}{l}\text { う称䦎に施肥し，ロータ } \\
\text { リーで耕うんする。 }\end{array}$ & $\begin{array}{l}8 \text { 月下 } \\
2 \text { 月上旬 } \\
\text { 3月上旬 } \\
5 \text { 月下旬 }\end{array}$ & $\begin{array}{l}\text { 機 械 } \\
\text { 人 } \\
\text { 人 }\end{array}$ & $\begin{array}{l}\text { ロータリー } \\
\text { 培 土板 }\end{array}$ & $\begin{array}{r}\text { 時閏 } \\
4 \text { 年生 } \\
42.9 \\
5 \text { 年生 } \\
34.0\end{array}$ & 1 & 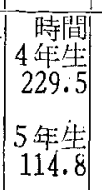 & $\begin{array}{l}5 \text { 年生は } 1 \text { う杍扔 } \\
\text { き有機資材を投 } \\
\text { 入する。 }\end{array}$ \\
\hline $\begin{array}{l}\text { 耕 } \\
\text { う } \\
ん \\
\text { 除 } \\
\text { 草 }\end{array}$ & $\begin{array}{l}\text { うね間をロータリーで耕 } \\
\text { うんし，4年生の株元は } \\
\text { 除草剤で除草する。 }\end{array}$ & $\begin{array}{l}\text { 11月上 中中旬 } \\
\text { (2) } 2 \text { 月中～下旬 } \\
\text { ( } 4 \text { 月上～中旬 } \\
\text { ( } 6 \text { 月上～中旬 } \\
\text { ( } 7 \text { 月上～中旬 }\end{array}$ & $\begin{array}{c}\text { 機 械 } \\
\\
\text { 人 力 }\end{array}$ & $\begin{array}{l}\text { ロータリー } \\
\text { 動力櫴䨏機 }\end{array}$ & $\begin{array}{l}25 \\
25\end{array}$ & $\begin{array}{l}1 \\
2\end{array}$ & $\begin{array}{l}25 \\
50\end{array}$ & $\begin{array}{l}\text { ○印の耕うん除草 } \\
\text { の際, 株元の手抜 } \\
\text { 作業を実施する。 }\end{array}$ \\
\hline $\begin{array}{l}\text { 满 } \\
\text { 害 } \\
\text { 虫 } \\
\text { 防 } \\
\text { 除 }\end{array}$ & $\begin{array}{l}\text { 嘪口にはスワーススプレ } \\
\text { ヤ用広幅散布ノズルを使 } \\
\text { 用する。 }\end{array}$ & $\begin{array}{c}3 \text { 月下 } \\
4 \text { 月上旬 } \\
4 \text { 月上〜中旬 } \\
5 \text { 月下 } \\
6 \text { 月上旬 } \\
6 \text { 月中〜下旬 } \\
7 \text { 月下 } \\
8 \text { 月上旬 } \\
9 \text { 月上〜中旬 } \\
\text { 11月下 } \\
12 \text { 月上旬 }\end{array}$ & 機 械 & $\begin{array}{l}\text { スワースス } \\
\text { プレーヤ }\end{array}$ & 45 & 2 & 90 & 和間 9 回散布 \\
\hline 摘 & 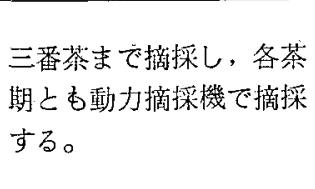 & 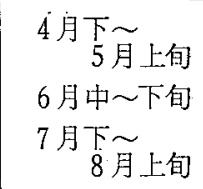 & 機 械 & $\begin{array}{l}\text { 皇走式動力 } \\
\text { 摘採機 }\end{array}$ & $\begin{array}{r}4 \text { 年生 } \\
33.2 \\
5 \text { 年生 } \\
38.2\end{array}$ & 2 & $\begin{array}{r}4 \text { 年生 } \\
68.2 \\
5 \text { 年生 } \\
76.5\end{array}$ & \\
\hline $\begin{array}{l}\text { 整 } \\
\text { 枝 }\end{array}$ & $\begin{array}{l}\text { 一番茶前, 動力摘採機で } \\
\text { 整枝する。 }\end{array}$ & $\begin{array}{l}2 \text { 月下 } \\
3 \text { 月上旬 } \\
5 \text { 月上 中旬 }\end{array}$ & 機 峨 & $\begin{array}{l}\text { 自走式動力 } \\
\text { 摘操機 }\end{array}$ & $\begin{array}{r}4 \text { 年生 } \\
21.5 \\
5 \text { 年生 } \\
21.0\end{array} \mid$ & 2 & $\left|\begin{array}{r}4 \text { 年生 } \\
157.1 \\
5 \text { 年生 } \\
41.9\end{array}\right|$ & $\begin{array}{l}4 \text { 年生は春整枝の } \\
\text { 枝条をさし穂よし } \\
\text { て使用する。 }\end{array}$ \\
\hline 計 & & & & & $\begin{array}{l}4 \text { 年生 } \\
192.6 \\
5 \text { 年生 } \\
188.2\end{array}$ & & $\begin{array}{c}4 \text { 年生 } \\
699.8 \\
5 \text { 年生 } \\
478.2\end{array}$ & \\
\hline
\end{tabular}

\section{5 摘}

要

茶園造成から 5 年目むでの幼木茶園における省力管理 作業の体系について，1966 ’70年まで5年間にわたって 検討した。その結果を要約すると次のと抏りである。

1. 茶園造成では定植瑇掘りに最も労力を要した。こ れがトラクタによる機械掘りによって人力の場合の 13.1 \%となり，大幅に省力化できた。

2. 株元雑草の妨茶樹におよ湮す影響は，30日以上の 草生により悪影響が認められるので，30日以内に除草す
る必要がある。一方，5ね間の機械除草は雑草の草丈 15 $\mathrm{cm}$ 以内で実站することにより除草効果が得られ省力化が はかられた。

3. 病害蚴除の省力方法としてスワーススプレーヤ と動力噴霛機について作業比較した結果，スワーススプ レーヤの機械作業時間は $10 \mathrm{a}$ 当たり27.5分で動力喷霧機 の $41.8 \%$ ，組作業の全投下労㗢時間は $32.2 \%$ となり大幅 に省力化された。

4. 収量調査の結果は $10 \mathrm{a}$ 当たり 3 年目 $108.6 \mathrm{~kg}, 4$ 年目 $395.5 \mathrm{~kg} ， 5$ 年目 $732 \mathrm{~kg}$ であったが，多収を得る方 
法としては栽植密度の増加汃必要と思われた。

5. 5 年間にわたる累積調查の結果から幼木茶園省力 管理作業技術を総合的に組み合わせると，1 ha 当たりの 年間所要労㗢特間は定植当年 989.7時間，2年目 621.6 時 間， 3 年目723. 1時間， 4 年目699.8時間， 5 年目 478.2 㭙 間まで省力化できる体系が基盤整䚚と機械装備を前提と して可能であると判断された。

6. この管理技術体系をさらに上り生産性の高い6の にするために必要な残されたおもな技鯶的閣題点は次の 2 点であった。

1 機械化専用茶園の年理特性の解明と载培技術の碓 泣。

口，種苗費および定植䚉用の経営費用中に. 占める比重 が高いので，去苗法の簡易化ならびに植いたみ防」 技術の確立など定植技術についての再族討。

\section{6 引 用 文 献}

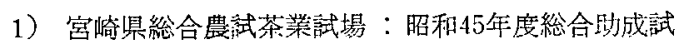
験事業成續畵， $1 \sim 5$ (1970).

2）農業機柀学念編：農業機械ハンドブック.

3）鹿览島県茶試：昭和44年度農林省総合勋成詩験事 業成績書，3５9（1969）。

\section{Summary}

To establish the organization of labour-saving management in the young tea field, some examinations had been carried out from 1966 to
1970.

The result can be summarized as follows.

1. It took so much time to dig the ditch by hand for transplanting, but the use of tractor with 16 inched bottom plow in large saved about $13 \%$ of time.

2. Thick growth of weed had a worse effect upon the growth of young tea plant, so the weeding at intervals of thirty days was necessary for young tea plant.

The mechanical weeding with rotary tiller had a better effect within $15 \mathrm{~cm}$ of weed height.

3. To control tea pests and disease, the power sprayer and swath sprayer were used, the latter's working time being $27.5 \mathrm{~min} / 10 \mathrm{a}$, about $42 \%$ of the former's one.

4. The yield of tea leaves was $108.6 \mathrm{~kg} / 10 \mathrm{a}$ in the third year, $395.5 \mathrm{~kg} / 10 \mathrm{a}$ in the fourth year, and $732 \mathrm{~kg} / 10 \mathrm{a}$ in the fifth year from planting.

5. From these experiments, making the larger compartment of tea field and equipment with some farm machinery were confirmed to be necessry to establish the organization of laboursaving management in the young tea field, and several pending problems had been arisen.

(Mar. 28, 1972) 